ガス油荙除く編合物の $12,16.5,8.5 \%$ であり， $\mathrm{CH}_{2}$ 基水よる反応を示す。不飽和炭化水素々縮合物の70\% に潐する。接触水添物のラマンスペクトルKよれば $69 \sim 126.5^{\circ} \mathrm{C}$ 溜分々それに相当する直鎖の岸化水素上 บ交る。

$66 \sim 68.5^{\circ} \mathrm{C}$ 溜分は $\mathrm{C}_{6} \mathrm{H}_{14}$ の他に $10 \%$ の 2-x チルペンタンとー25\%の3ーメチルペンタンとを, 27

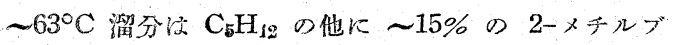

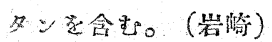

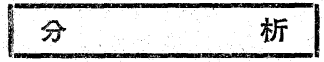

U.D.C. $545: 662.75$

\section{原湠むよび石油溜分中に含まれる 微量金属の分数法}

(C. J. Milner et al., Anal. Chem.,

24, 1728 (1952); J. H. Karchmer \&

E. L. Gunn, Ind. Eng. Chem., 24, 1733 (1952))

原油中に含染れる微量の金属の精密分析に於する石
油工業関保者の関心々単に比較地質学的研究のために

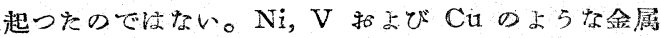
はクラッキング触媒を用いる際にその活性を減退さ些 たり，生成品に粗惡な性状を与えるなど好委しくない 性質を持つている。またある種の製品では金属の痕跡 が著しく障碍になることがある。

Milner などは 10-5\%あるいはそれ以下の念量の $\mathrm{Fe}, \mathrm{Ni}, \mathrm{V}$ 和よび $\mathrm{Cu}$ の定量法に関して詳細な報告 を行っている。これによると灰化は濃硫酸を用いた湿 式で行い，特に揮発性金属化合物の存在する時に都合 よいよらにしてある。Ni，Fe および V の定量分析 は是色反度を利用して光麗比色法を行い，Cuはポー ラログラフでIcc'の検液を一定のせルを用いて測定 している。

Karchmer 泣一般問題を検討し, さらに数線スペク トルの直接または間接法の応用至報じている。特に前 渚は迅速性々灰化損失が避けられるたはに明らかにこ の問題の劃期的解決法であるといい得る。(鈴木)

\section{3 物理学, 54 化学}

リグニンとりグニン化研究 XI. バガスリグニンの構 湝研究 G. de Stevens et al., J.Am. Chem. Soc., 75. No. 2, 305 (1953)

ガス测熱法 监, $\mathbb{N}$. J. T. Clarke et al., J.Am.

Chem. Soc., 75, No. 4, 781, 785 (1953)

有機微量定量法の最近の進步 W. Kirsten, Anal.

Chem., 25, No. 1, 74 (1953)

グルマニウム分析法 H. H. Krause et al., Anal.

Chem., 25, No. 1, 134 (1953)

塩素㯰換メタン和よびェタン定量法 R.B. Bernstein et al., Anal. Chem., 25, No. 1, 139 (1954)

潤滑油中の微量物のスペクトル的定量法 R. F.

Meeker et al., Anal. Chem., 25, No. 1, 151 (1953)

石油溜分からの芳香族類中の芳香族扣よびナフテン襄

定量法 C. C. Martin et al., Anal. Chem., 25, No. 2, 206 (1953)

流動性試料を用いるポーラログラフ分析 L. D. Wilson, Anal. Chem., 25, No. 2, 218 (1953)
合成ガス分析 G. L. Barthaver et al., Anal. Chem., 25, No, 2, 256 (1953)

后導度による炭酸がス連続記錄ＲＲ．D.Goodwin， Anal. Chem., 25, No. 2, 263 (1953)

石油中の塩基性䇪菜定量法 V. Z. Deal et al., Anal. Chem., 25, No. 3, 426 (1953)

有機物留の酸素七ミミク口毞量法 R. D. Hinkel, Anal. Chem., 25, No. 3, 470 (1953)

$\mathrm{C}_{9}$ よび $\mathrm{C}_{10}$ 芳香族類の紫外線吸收定量法 M. S. Morris et al, Anal. Chem., 25, No. 1, 183 (1953) 溶解酸素のセミミクロ定量法 E. L。 Harper, Anal. Chem., 25, No. 1, 187 (1953)

赤外線スペクトえと構造の関係 J. Bomstein, Anal.

Chem., 25, No. 3, 512 (1953)

\section{0 工業の一般共通問題， 621 機械工学}

蒸汽動力発生の進步 F. X. Gilg, Blast Frinace \& Steel Plant, 41, No. 2, 220 (1953)

燃燒ガスタービンとその応用 B. C. Hatch, Elect. Eng., 72, No. 3, 252 (1952) 
ハイロント用の小型高压ポンプ R. W. Hitesbue et al., Mech. Eng., 75, No. 3, 205 (1953)

ASME ボイラ䙺定 WII. 改訂和上び特殊委員会 1952 -1935 A. M. Greene, Mech. Eng., 75, No. 3, 211 (1953)

地下のジーゼ几動力裝置 J. H. East, Mining Congr. J., 39, No. 1, 22 (1953)

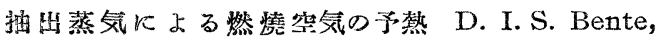
Combrstion, 24, No. 7, 57 (1953)

1952年に招ける動力関俩活動 Combristion，24, No.

7, 43 (1953)

ジーゼル然料の脫酼 W. Ohme, Erdöl $u$. Kohle,

6, No. 1, 8 (1953)

ジーゼルェンジン冷却の最近の倾问 E. Martin, $O i l$

Engine \& Gas T'urbine, 20, No. 236, 362 (1953) 小型ジーゼルェンジンの普及から生ずる問題について

—第2 新— J. H. Pitchford, Oil Engine \&

Gas T'urbine, 20, No. 236, 366 (1953)

最近のエンジンの大型化 Oil Engine \& Gas T Turbine,

20, No. 236, 382 (1953)

米国の新式掃海艇の補助用ガスタービン G. Waller,

Oil Eingine \& Gas Turbine, No. 236, 374 (1953)

断続的使用を目的とする海軍のガスタービン Oil

Eigine \& Gas T'urbine, 20, No. 236, 378 (1953)

\section{2 鉱山工 学}

絬結炭の軟化性 J. Bronowski et al., Nature, 171, No. 4348,389 (1953)

ダスト試料の試験 V. Simons, Colliery Eng., 30,

No. 349,99 (1953)

脑山涌気の蓺力学 C. J. Hall, Colliery Eng., 30,

No. 349, 102 (1953)

石岸坑の排水：工業用廃品 H. R. Murdock, Ind.

Eng. Chem., 45, No. 1, 101A (1953)

国連会議に和ける選炭，地下ガス化拒上び乾溜の䛺問

题 H. Kellerwessel et al., Erdöl u. Kohle, 6,

No. 2, 78 (1953)

宸浣若返 D工事 E. H. Browne, Colliery Guardian, 186, No. 4799, 219 (1953)

ファン陚験法 Colliery Gualdian, 186, No. 4799, 242 (1953)

石炭選炭の経费 Flehmig, Glïckauf, 89, No. 3〜 4, 72 (1953)

選炭工程飞和ける湿式遠心分離器の構造と操業 $\mathrm{E}$.

Hoffmann, Glü̈ckauf, 89, No. 5〜6, 105 (1953)
一酸化炭素による危害 G. Lehmann, Glïckarif, 89, No. 5 6; 129 (1953)

\section{0 化学工学, 化学萗品の製造, $662.1 / .5$ 爆蒋}

固体触媒の活性 W. B. Args et al., Ind. En $n_{S}$.

Chem., 45, No. 2, 298 (1953)

化学工業の將来の傾向 F. J. Soday, Ind. Eng.

Chem., 45, No. 2, 322 (1953)

多成分蒸溜 Oil Gas $J$., 51, No. 46, 182 (1953)

分溜器設計反ついて R. R. White, Petroleum Processing, 8, No. 3, 357 (1953)

精製裝置の化学的洗浮法 Oil Gas J., 51, No. 46, 211 (1953)

流動触媒分解裝置のエロジョン防正 J. S. Clarke, Oil Gas $J .$, 51, No. 46, 262 (1953)

䇠峃な熱交換器設計一而 C. H. Gilmour, $C h \mathrm{~cm}$.

Eng., 60, No. 4, 214 (1953)

蒸気一ガス混合物用冷却凝縮器の設計 G. H. Bras, Chem. Eng., 60, No. 4, 223 (1953)

蒸 発 E. E. Lindley, Chem. Eng., 60, No. 4, 227 (1953)

白由成分蒸溜のノモグラフ計算法 W. Schotte et $a l$ 。 Ind. Eng. Chem., 45, No. 2, 472 (1953)

\section{$662.61 / .69$ 燃燒，燃料一般}

空氛中に指ける可燃範围の新しい測定法 J.H. Burgoyne et al., Fuel, 32, No. 1,5 (1953)

架気中に括りる有機性可燃物の可燃性的よび自然発火 の限界 J. H. Burgoyne et al., Fwel, 32, No. 1, 17 (1953)

減圧下の火焰溫度測定用の小燃燒室 V. E. Henny， Fuel, 32, No. 1, 36 (1953)

$662.7 / .8$ 熱的または 化学的処理によつて作られる燃料

発熱量の自動制御 Gas World, 139, No. 3578, 714 (1953)

ガス消費の傾向 Gas World，137，No. 3577，648 (1953)

スコットランドに和りる乾溜括よびガス化用炭 $\mathrm{E} . \mathrm{A}$.

C. Chamberbain, Colliery Guardian, 186, No. 4802, 311 (1953)

新式ガス䊑製裝置 G. Baumann, Stahl ఒ。 Eisen, 73, No. 8, 492 (1953)

ガス工業に据けるプラステック J. W. J. Estevez, 
Gas World, 137, No. 3579, 791 (1953)

然料技術面に衫けるアメリカの進步 Gas World,

137, No. 3579, 792 (1953)

石炭灰中のゲルマウ二ム～K. Steward, Gas World，

137, No. 3579, 794 (1953)

\section{$6654 / .5$ 鉱物性油脂，石油，鉱油の処理}

英国に和けるぺトロケミカル工業一II H. K.

Whalley, Coke \& Gas, 15, No. 165, 61 (1953)

炭化水素からアセチレン C. J. Coberly et al.,

Pet' oleum Processing, 8, No. 3, 377 (1953)

吸收法に上る芳香族類の分離 F. R. Shuman et al.,

Oil Gas J., 51, No. 48, 109 (1953)

\section{7 タールエ 業}

石炭タール加工の新しい考光方 C. J. Hansen,

Biennstoff Chem., 34, No. 1 2, 4 (1953)

石炭と石炭製品加らの成型体 W. Kaufmann,

Bi ennstoff Chem., 34, No. 1 2, 6 (1953)

タール溜分に対する光の作用 C. R. Kinney et al.,

Ind. Eng. Chem., 45, No. 4, 809 (1953)

歴青炭タールのアンスラセン油の塩基について
Kruber et al., Berichte, 86, No. 3, 309 (1953)

歴青炭タールのアンスラセン油の考察 Kruber et al., Beichte, 86, No. 3, 366 (1953)

グリセロールそ液状トリェチレングリコールによるコ 一ルタール炭化水素加らのフェノールの分離 $J$. Applied Chem., 3, No. 3, 98 (1953)

歴青炭タールビ,チの 10.11-と 11.12-ベンダフルォ ランセンKついて Kruber et al., Berichte, 86, No. 4, 534 (1953)

669 治金, 合金, 金属材料

純酸素によるトーマス粗鉄の精畭 F.A. Springorum et al., Stahl u. Eisen, 73, No. 1, 6 (1953)

最近に和ける高所ガス精製の発展 K. Guthmann, Stahl थ. Eisen, 73, No. 5, 283 (1953)

熔鉣炉和よびキュポラ内の圧力降下 S. Ergun, Ind.

Eng. Chem., 45, No. 2, 477 (1953)

コークス評価計画の实施 B. P. Mulcaby, Blast

Fu' nace \& Steel Plant, 41, No. 4, 408 (1953)

冶金学研究火怙ける試料探取 W. Oelsen, Stahl $u$.

Eisen, 73, No. 8, 495 (1953)

燃料之金属一 I Coke \& Gas, 15, No. 166, 89 (1953)

\section{お 知 ら 世}

\section{学術会議会員候補者推䳡の件}

\begin{tabular}{|c|c|c|c|c|c|c|}
\hline 上 & 春 & 成 氏 & 第 & 5 部 & 全 国 & 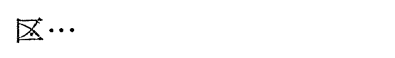 \\
\hline 塚 & 誠 & 之氏 & 第 & 5 部 & 全 国 & 区・国鉄技稒試験所所長 \\
\hline 塚 & 忠 比 & 古 氏 & 第 & 5 部 & 全 国 & 区…東洋高压鉱業所取繶役 \\
\hline 玉 & 信 次 & 郎 氏 & 第 & 5 部 & 全 国 & 区…京都大学敉授 \\
\hline 藤 & 正 & 典 氏 & 第 ${ }^{1}$ & 5 部 & 全 国 & 区…大阪府工業獎励館長 \\
\hline 川 & 一 & 郎 氏 & 第 & 5 部 & 中部地 & 区…名古屋大学敉授 \\
\hline 川 & 正 & 夫 氏 & 第 & 5 部 & 全 国 & 区…八幡製鉄所常務取縍役 \\
\hline
\end{tabular}

社団法人 燃料協会 